\title{
STUDI HABITAT DAN PENGANGKUTAN SISTEM TERTUTUP PADA IKAN RONO Oryzias sarasinorum POPTA, 1905 ENDEMIK DANAU LINDU SEBAGAI DASAR UNTUK DOMESTIKASI
}

\author{
Muh. Herjayanto ${ }^{1,4, *}$, Abd. Waris ${ }^{2,5}$, Yulianti Suwarni ${ }^{2,5}$, Mudabbirah Halia ${ }^{2,5}$, Abdul Gani ${ }^{3}$, Nugra \\ Findayani $^{2,5}$, Regita Cahyani ${ }^{2,5}$ \\ ${ }^{1}$ Mahasiswa Doktoral, Program Studi Ilmu Akuakultur, Sekolah Pascasarjana, Institut Pertanian Bogor \\ Jln. Raya Dramaga, Kampus IPB Dramaga, Bogor 16680 \\ ${ }^{2}$ Mahasiswa Program Studi Akuakultur, Fakultas Peternakan dan Perikanan, Universitas Tadulako \\ Jln. Soekarno Hatta Km.9, Tondo, Mantikulore, Kota Palu 94118 \\ ${ }^{3}$ Dosen Program Studi Akuakultur, Fakultas Perikanan, Universitas Muhamadiyah Luwuk \\ Jln. KH Ahmad Dahlan No. 79, Luwuk 94712 \\ ${ }^{4}$ Masyarakat Iktiologi Indonesia (MII) \\ ${ }^{5}$ Himpunan Mahasiswa Perikanan (HIMARIN), Fakultas Peternakan dan Perikanan, Universitas Tadulako \\ *fherja@yahoo.com
}

\begin{abstract}
Abstrak
Oryzias sarasinorum atau disebut rono oleh masyarakat setempat merupakan ikan endemik di danau Lindu, Sulawesi Tengah, Indonesia. Ikan ini terancam punah di habitatnya, sehingga domestikasi (pemeliharaan dan pengembangbiakan) di lingkungan terkontrol mendesak dilakukan sebagai salah satu upaya konservasi. Salah satu dasar domestikasi ikan liar adalah pengetahuan terhadap habitat mereka. Tahap selajutnya yaitu membawa ikan tersebut dari habitat aslinya ke lingkungan terkontrol. Masalah pengangkutan ikan dengan sistem tertutup yaitu kematian, sehingga perlu penggunaan zeolit, arang aktif dan garam dalam air media pengangkutan. Perlakuan yaitu penambahan $20 \mathrm{~g}$ zeolit $+10 \mathrm{~g}$ arang aktif pada media air tanpa garam (A), $1 \mathrm{~g} \mathrm{~L}^{-1}$ garam (B), $2 \mathrm{~g} \mathrm{~L}^{-1}$ (C) dan tanpa zeolit, arang aktif dan garam (D). Tujuan penelitian yaitu menganalisis beberapa karekteristik habitat, sintasan selama pengangkutan dan pemeliharaan pascapengangkutan. Habitat ikan rono di pesisir Lovu danau Lindu memiliki dasar landai, substrat pasir kasar, warna air cokelat-teh, terdapat serasah, tanaman air Phragmites karka. Juwana dan larva ikan rono berenang bergerombol di sekitar tanaman dala yang terendam air. Ikan rono muda dan dewasa terlihat makan di atas substrat dasar perairan. Spesies ikan lain yang ditemukan di habitat ini yaitu nila Oreochromis sp., sepat Trichopodus sp., serta Gambusia affinis. Penambahan zeolit dan arang aktif selama pengangkutan dapat meningkatkan sintasan ikan rono dibandingkan tanpa penambahan. Perlakuan A menghasilkan sintasan yang lebih tinggi 62,50\% dibandingkan $\mathrm{B}$ dan 37,50\% dibandingkan $\mathrm{C}$ selama pemeliharaan pascapengangkutan pada penelitian ini.
\end{abstract}

Kata kunci: Habitat, ikan endemik, Oryzias sarasinorum, pengangkutan

\section{STUDY HABITAT AND CLOSED SYSTEM TRANSPORTATION OF SARASIN'S BUNTINGI Oryzias sarasinorum POPTA, 1905 ENDEMIC LAKE LINDU AS THE BASIS FOR DOMESTICATION}

\begin{abstract}
Oryzias sarasinorum or called rono by the local community is endemic fish in Lake Lindu, Central Sulawesi, Indonesia. This fish is endangered in its habitat, so domestication (maintenance and breeding) in controlled environment is urgently as one of the conservation efforts. One basic of wild fish domestication is the knowledge their habitat. The next stage is bring the fish from its natural habitat to a controlled container. The problem of transporting fish with closed system is mortality, so it is necessary to use zeolite, activated charcoal and salt in the water transport medium. The transport treatment is the addition 20 g zeolite $+10 \mathrm{~g}$ activated charcoal in water media without salt (A), $1 \mathrm{~g} \mathrm{~L}^{-1}$ salt (B), $2 \mathrm{~g} \mathrm{~L}^{-1}$ salt (C), without zeolite, activated charcoal and salt (D). The purpose of the study to assess some habitat characteristics, survival during transportation and maintenance post-transportation. Habitat of rono in Lovu coast is sloping base, coarse sand substrate, tea-brown water color, there are leaf litter and water plant Phragmites karka. Juvenile and larvae rono swim clustered around plants in water. Young and adult are seen feeding on the bottom substrate. Other fish species found in this habitat are Oreochromis sp., Trichopodus sp., and Gambusia affinis. The use of zeolite and activate charcoal in water transportation media can increase the survival of rono than without using that. Treatment A resulted in a higher survival $62.50 \%$ than $\mathrm{B}$ and $37.50 \%$ compared to $\mathrm{C}$ during maintenance post-transportation in this study.
\end{abstract}

Keywords: Endemic fish, habitat, Oryzias sarasinorum, transportation

\section{PENDAHULUAN}

Ikan rono adalah nama lokal untuk spesies Oryzias sarasinorum (Gani et al. 2015) yang merupakan endemik danau Lindu, Sulawesi Tengah (Parenti 2008). Ikan ini juga dikenal dengan nama Sarasin's buntingi atau Sarasin's minnow. Ikan rono tercatat sebagai spesies terancam punah tahun 1996 dalam International Union for Conservation of Nature (IUCN) Red List Threatened Animals
(Lukman 2007). Diduga persaingan memperoleh makanan dan pemanfaatan ruang dengan ikan introduksi (Gani et al. 2015) serta gangguan antropogenik menjadi penyebab ikan ini terancam punah. Kriteria tersebut merupakan peringatan bahwa spesies ini secara kritis tidak terancam tetapi menghadapi resiko kepunahan yang tinggi di alam dan dalam tempo yang tidak lama (Lukman 2007). Ikan rono oleh masyarakat sekitar danau juga menjadi salah satu ikan konsumsi. Oleh karena itu, 
kegiatan domestikasi melalui pemeliharaan dan pengembangbiakannya secara ex-situ pada wadah terkontrol mendesak untuk dilakukan. Kedepannya benih hasil pengembangbiakan tersebut dapat ditebar kembali ke danau Lindu untuk menjaga kelestariannya.

Salah satu dasar manipulasi pemeliharaan ikan di wadah terkontol yaitu pengetahuan habitat ikan tersebut di alam. Kajian ini juga diperlukan sebagai dasar pertimbangan dalam pengelolaan agar dimanfaatkan secara berkelanjutan (Haryono et al. 2017). Informasi habitat ikan rono di danau Lindu telah dilaporkan oleh Rasmina (2014) dan Gani et al. (2015). Pengetahuan terhadap karakteristik habitat ikan rono di alam diharapkan dapat memudahkan manipulasi pemeliharaannya di wadah terkontol.

Tahap selajutnya untuk kegiatan domestikasi ikan liar yaitu membawa ikan tersebut dari habitat aslinya di alam ke wadah terkontrol. Kegiatan membawa ikan atau pengangkutan perlu diperhatikan karena sangat menentukan kondisi ikan saat pemeliharaan pascapengangkutan. Menurut Yustiati et al. (2017), pengangkutan yang kurang baik dapat menyebabkan stres yang berdampak pada kematian ikan dalam perjalanan atau saat pemeliharaan. Menurut Nirmala et al. (2012) efek stres dari pengangkutan yang selanjutnya berdampak terhadap sintasan (survival) ikan berlangsung sekitar dua minggu. Teknik pengangkutan yang umum digunakan salah satunya adalah sistem tertutup yaitu menggunakan plastik atau wadah lainnya yang diisi air sebagai media dan ditutup rapat.

Permasalahan dalam sistem pengangkutan tertutup yaitu meningkatnya ammoniak $\left(\mathrm{NH}_{3}\right)$ dan karbon dioksida $\left(\mathrm{CO}_{2}\right)$ di air media yang berasal dari hasil metabolisme ikan (Supriyono et al. 2011 dan, Nirmala et al. 2012). Saat kadar gas toksik tersebut mencapai level jenuh di air media transport, maka $\mathrm{NH}_{3}$ dan $\mathrm{CO}_{2}$ dalam darah sulit untuk diekskresikan melalui insang, sehingga kadarnya akan meningkat. Kondisi demikian mengakibatkan ikan menderita hipercapnia dan acidosis, selanjutnya ikan akan kekurangan oksigen $\left(\mathrm{O}_{2}\right)$ yang dapat mengakibatkan kematian (Nirmala et al. 2012).

Konsentrasi senyawa toksik terutama $\mathrm{NH}_{3}$ dapat dikurangi dengan menambahkan zeolit dan arang aktif, karena bahan tersebut berfungsi sebagai adsorban $\mathrm{NH}_{3}$ (Zhang \& Perschbacher 2003, Supriyono et al. 2007, Supriyono et al. 2011, Nirmala et al. 2012). Kemudian penambahan garam dalam air media pengangkutan berfungsi untuk menurunkan gradien tekanan osmotik antara cairan tubuh ikan dengan air media serta menurunkan toksisitas $\mathrm{NH}_{3}$ (Nirmala et al. 2012). Oleh karena itu, diharapkan penggunaan zeolit, arang aktif dan penambahan garam dapat mendukung sintasan ikan rono $O$. sarasinorum selama pengangkutan dan pemeliharaan pascapengangkutan.

\section{METODE}

\section{Pengamatan habitat}

Pengamatan habitat ikan rono Oryzias sarasinorum di lokasi penangkapan dilakukan dengan cara mengamati dari permukaan air menggunakan perahu dan pengamatan bawah air menggunakan snorkeling. Pengamatan dilakukan terhadap keberadaan ikan rono dewasa, juwana dan larva, jenis substrat dasar perairan dan tingkah laku ikan rono pada substrat tersebut. Selain itu, dilakukan pula wawancara dengan masyarakat setempat untuk memperoleh informasi habitat, jenis tumbuhan air, dan spesies ikan lain yang berada di tempat penangkapan ikan rono. Titik koordinat habitat ikan tempat penangkapan ditandai menggunakan Global Positioning System (GPS).

\section{Penangkapan ikan}

Penangkapan ikan dilakukan pagi hari menggunakan jaring pantai dengan ukuran mata jaring 5,5 mm, panjang $10 \mathrm{~m}$ dan lebar 1,2 m. Jaring dilengkapi pemberat dan pelampung untuk memudahkan pengoprasiannya di danau. Jaring dioperasikan pada kedalaman < 1,5 m oleh empat orang, dua orang di masing-masing ujung jaring, satu orang di tengah jaring bagian belakang dan satu orang mengusir ikan dari depan jaring.

Jaring dibentangkan kemudian digiring perlahan ke tepi danau sambil kedua ujung jaring dipertemukan sehingga membentuk lingkaran yang semakin kecil dan ikan akan terkumpul di bagian tengah. Ikan perlahan diambil menggunakan gayung dan dimasukkan ke dalam loyang dengan kepadatan rendah dan dilengkapi aerator portable sebagai penyuplai oksigen terlarut. Saat penangkapan diharuskan agar ikan tidak tergesek dengan jaring dan tidak diangkat ke luar dari air karena akan stres dan mati dengan ciri awal warnanya mulai kehitaman dan berenang pelan dipermukaan. Selanjutnya ikan diangkut menggunakan perahu menuju pesisir danau di desa Tomado untuk memudahkan pengepakan dan pengangkutan. Ikan terlebih dahulu dimasukkan ke dalam jaring yang dibuat menyerupai keramba dan ditempatkan di pesisir danau selama 20 jam. Jaring tersebut memiliki ukuran mata jaring $2 \mathrm{~mm}$.

\section{Pengepakan dan pengangkutan}

Pengepakkan ikan mengikuti metode Nirmala et al. (2012) yang dimodifikasi. Pengepakkan menggunakan kantong plastik packing bening. Zeolit dan arang aktif masing-masing diikat dengan kantong kain kecil. Kantong packing diisi air sebanyak $1 \mathrm{~L}$ yang sebelumnya dicampur dengan garam krosok berdasarkan perlakuan pengangkutan. Perlakuan yang digunakan yaitu penambahan $20 \mathrm{~g}$ zeolit $+10 \mathrm{~g}$ arang aktif, tanpa garam (A), $20 \mathrm{~g}$ zeolit $+10 \mathrm{~g}$ arang aktif $+1 \mathrm{~g} \mathrm{~L}^{-1}$ garam (B), $20 \mathrm{~g}$ zeolit $+10 \mathrm{~g}$ arang aktif $+2 \mathrm{~g} \mathrm{~L}^{-1}$ garam (C) dan tanpa zeolit, arang aktif dan garam (D). Masing-masing perlakuan tersebut diulang sebanyak tiga kali. 
Ikan dimasukkan secara perlahan ke dalam plastik packing dengan kepadatan 4 ekor $\mathrm{L}^{-1}$. Selanjutnya oksigen murni dimasukkan dan ujung kantong packing diikat dengan karet pengikat. Ikan selanjutnya diangkut menuju tempat pemeliharaan selama 5 jam perjalanan darat. Setelah sampai, jumlah ikan dihitung untuk mengetahui sintasan selama pengangkutan.

\section{Pemeliharaan pascapengangkutan}

Pemeliharaan pascapengangkutan dilakukan selama 16 hari untuk perlakuan yang memiliki sintasan $>50 \%$ selama pengangkutan. Pemeliharaan ikan rono menggunakan wadah bervolume 1,5 L. Wadah tersebut terlebih dahulu dibersihakan, dijemur di bawah sinar matahari dan kemudian diisi air tawar sebanyak 1 L. Setiap wadah ditambahkan aerasi untuk menyuplai oksigen terlarut, serta methylene blue 0,2 g untuk pencegahan jamur. Selama pemeliharaan ikan diberikan pakan dua kali sehari (pagi dan sore) berupa nauplii Artemia pada hari pemeliharaan ke 1 sampai 7, dan Moina sp. pada hari ke 8 sampai 16. Penyifonan dilakukan setiap pagi sebelum pemberian pakan. Pergantian air dilakukan tiap tiga hari sekali pada sore hari. Kualitas air pemeliharaan dikontrol pada kisaran kondisi optimum yaitu suhu $24-29^{\circ} \mathrm{C}$, pH 7,0-8,6 dan oksigen terlarut 3,0-6,9 $\mathrm{mg} \mathrm{L}^{-1}$ (Wilkerson 2013, Gani et al. 2015). Pengamatan sintasan ikan dilakukan setiap hari.

\section{Prosedur analisis data}

Data habitat, sintasan selama pengangkutan dan pemeliharaan pascapengangkutan yang diperoleh dianalisis secara deskriptif. Data tersebut disajikan dalam bentuk Gambar dan Tabel.

\section{HASIL DAN PEMBAHASAN}

\section{Deskripsi habitat ikan rono}

Lokasi penangkapan ikan rono Oryzias sarasinorum berada di bagian barat danau Lindu, wilayah desa Anca. Daerah ini diberi nama Lovu $\left(1^{\circ} 18 ’ 11,25^{\prime}\right.$ ' lintang selatan, 120'3'40,45" bujur timur) oleh masyarakat setempat (Gambar 1). Lokasi ini memiliki dasar yang landai, substrat pasir kasar (Gambar 2.a) dan ditemukan serasah di dasar perairan, warna air cokelat-teh, serta pesisirnya terdapat tumbuhan air yang didominasi oleh Phragmites karka atau masyarakat setempat menyebutnya tumbuhan dala (Gambar 2.b). Tumbuhan dala dapat tumbuh pada kedalaman $<1 \mathrm{~m}$ di pesisir Lovu.

Tidak banyak catatan tentang tumbuhan air danau Lindu. Jenis Cyperaceae, Graminae dan Pteridophyta dapat ditemukan di pinggir danau. Pada periode sebelum penebaran ikan tawes (tahun 1953) tumbuhan air seperti nase (Ceratophylum) dan daung (Limnaehemum) masih ditemukan di danau ini (Lukman 2007). Selain itu, ditemukan pula tanaman Limnochoris plava, Pistia stratiotes dan Nymphaea sp. dalam jumlah rendah (Lukman 2007 dan Rasmina 2014). Miskinnya tanaman air di danau Lindu tampaknya berkaitan dengan substrat dasar di wilayah tepian yang umumnya berupa pasir, serta tingkat kecerahan yang rendah. Selain itu, danau Lindu merupakan perairan yang tidak stabil. Danau Lindu akan dengan mudah mengalami proses pengadukan didorong adanya pengaruh dari luar seperti hembusan angin dan perubahan suhu. Proses pengadukan yang cukup intensif ditandai oleh kondisi air yang cenderung berwarna gelap. Pengadukan dapat memberikan keuntungan yang menunjang kesuburan perairan danau (Lukman 2007). Saat penangkapan ikan rono, air danau terlihat tenang saat pagi hari namun perlahan berombak setelah siang hari.

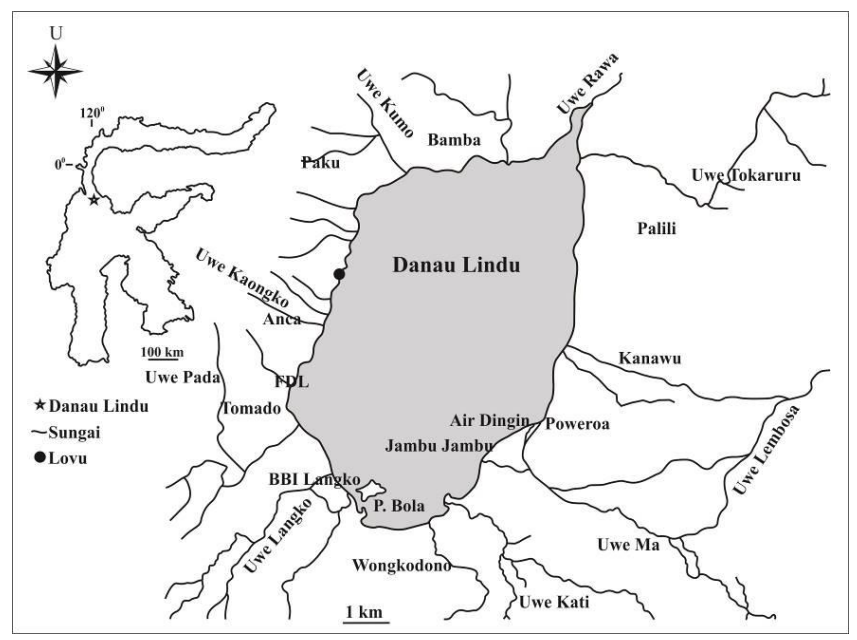

Gambar 1 Danau Lindu di Sulawesi Tengah Indonesia. Uwe adalah bahasa Kaili, Sulawesi Tengah untuk air, sedangkan singkatan $\mathrm{U}$ adalah utara dan $\mathrm{P}$ adalah pulau (Peta dimodifikasi dari Annawaty \& Wowor 2015). 


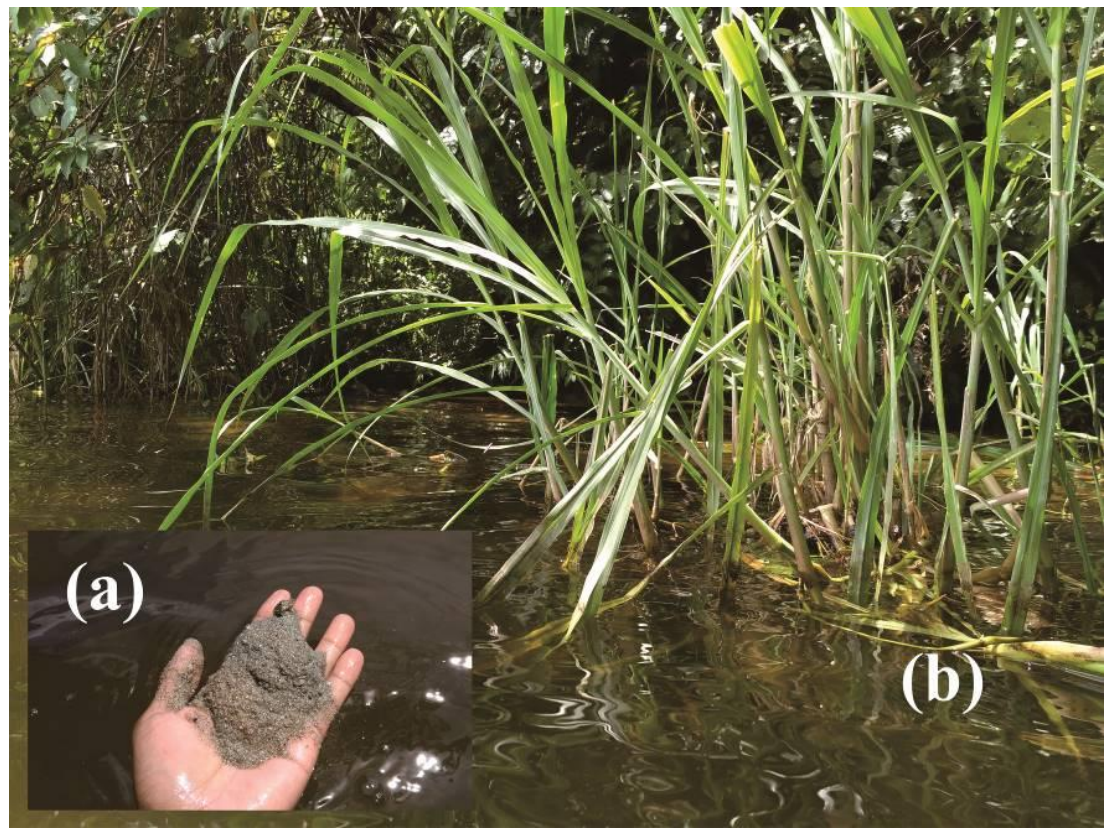

Gambar 2 Substrat pasir (a) dan Tumbuhan dala Phragmites karka (b) di Lovu, Danau Lindu Sulawesi Tengah Indonesia (Foto oleh M. Herjayanto).

Penambahan substrat pasir dalam wadah terkontrol untuk memelihara ikan rono $O$. sarasinorum dapat dilakukan meniru habitat alaminya. Namun, hal ini masih harus dikaji kembali. Menurut laporan Gani et al. (2015), selain pada perairan yang memiliki substrat pasir, ikan rono dapat ditemukan pada perairan danau Lindu yang memiliki substrat pasir berlumpur dan berlumpur. Pesisir Lovu yang memiliki substrat pasir berlumpur pada bulan September sampai Desember 2014 dilaporkan memiliki suhu $27-28^{\circ} \mathrm{C}$, kecerahan $<1 \mathrm{~m}$, pH 7,1-7,7 dan oksigen terlarut 6,0-6,8 $\mathrm{mg} \mathrm{L}^{-1}$.

Hasil pengamatan bawah air menunjukkan populasi ikan rono dewasa umumnya hidup secara bergerombol pada kedalaman 0,5-2 m, sedangkan juwana pada kedalaman $<1 \mathrm{~m}$. Pengamatan menunjukkan pada bagian tumbuhan dala yang terendam air banyak dijumpai juwana dan larva ikan rono. Hal ini mengindikasikan bahwa saat fase ini mereka membutuhkan tempat untuk berlindung. Kondisi demikian dapat dimanipulasi dalam wadah terkontrol dengan menambahkan tanaman air atau tali rafia yang dibuat menyerupai akar tanaman air. Menurut Gani et al. (2015) tumbuhan dala berfungsi sebagai tempat ikan rono mencari makan dan berlindung di danau Lindu. Lukman (2007) melaporkan dala tumbuh mendominasi di sisi timur selatan selatan danau ini. Selain itu, Rasmina (2014) melaporkan larva ikan rono di pesisir pulau Bola, danau Lindu terlihat berlindung di antara akar tumbuhan Pistia stratiotes serta batang bohon yang terendam air dan dipenuhi alga. Hal ini merupakan strategi dalam melindungi diri dari predator dan kompetitor.

Stadia juwana dan ikan muda spesies $O$. soerotoi endemik danau Tiu dilaporkan mendiami perairan dangkal yang ditandai dengan vegetasi yang lebat (Mokodongan et al. 2014). Spesies $O$. nebulosus endemik danau Poso dilaporkan dapat dijumpai pada perairan jernih di atas dasar substrat pasir, kerikil dan ranting (Parenti \& Soeroto, 2003). Spesies $O$. hadiatyae dilaporkan berasosiasi dengan akar Pandanus sp. yang menjadi karakteristik vegetasi pada pesisir danau Masapi yang dangkal (Herder \& Chapuis 2010). Kemudian untuk spesies rono Adrianichthys oophorus endemik danau Poso, Gundo (2016) melaporkan bahwa ikan ini hidup secara bergerombol di perairan terbuka pada kedalaman 5 sampai $7 \mathrm{~m}$ dengan dasar berbentuk lereng yang curam (pinggiran tubir), dan tidak ditemukan di perairan dangkal (kedalaman $\leq 2 \mathrm{~m}$ ). Saat siang, ikan ini mencari makan (terlihat dari formasi planktivores feeding) di perairan pinggir danau yang curam dengan substrat berbatu dan pasir berlumpur (kedalaman $>2 \mathrm{~m}$ ). Ikan A. oophorus kadang terlihat berenang dengan formasi kawanan jelajah (traveling school) $\pm 50 \mathrm{~cm}$ dari permukaan perairan saat kondisi perairan tenang tidak bergelombang.

Selain itu, ikan rono muda dan dewasa terlihat pula berenang bergerombol di permukaan substrat perairan sambil sesekali mulutnya dirapatkan di substrat. Pada saat tersebut, posisi ikan rono terlihat miring $45^{\circ}$ selama beberapa saat, dengan kepala di bawah dan ekor di atas. Diduga ini merupakan tingkah laku ikan rono saat makan di substrat. Jenis ikan lain yang ditemukan di lokasi ini yaitu ikan nila Oreochromis sp., sepat Trichopodus sp. dan Gambusia affinis (Poecilidae). Sarang ikan nila mudah ditemukan pada lokasi ini.

Spesies ikan nila merupakan salah satu jenis yang diintroduksi secara sangaja di danau Lindu. 
Ikan ini kemudian beradaptasi dengan baik sehingga menjadi spesies dominan pada perairan danau. Menurut Lukman (2007) tahun 1950-1958 diintroduksi lima spesies ikan (mas, tawes, mujair, sepat dan gurami) dan satu spesies lele tahun 1953 di danau Lindu. Sementara untuk ikan G. affinis belum ada catatannya, kami menduga ikan ini masuk secara tidak sengaja karena tercampur bersama ikan yang sengaja diintroduksikan di danau Lindu. Introduksi ikan nila masih terus dilakukan saat ini, terutama untuk menjaga stok ikan di danau Lindu.

\section{Sintasan selama pengangkutan}

Hasil pengamatan terhadap sintasan selama pengangkutan sistem tertutup ikan rono (Tabel 1), diketahui bahwa zeolit dan arang aktif memiliki peranan penting terhadap sintasan. Penambahan zeolit dan arang aktif dapat meningkatkan sintasan ikan rono yang lebih tinggi 87,50-91,67\% dibandingkan tanpa bahan tersebut. Transportasi ikan rono tanpa menggunakan zeolit, arang aktif dan penambahan garam menghasilkan sintasan yang rendah $<50 \%$. Telah dilaporkan bahwa zeolit dan arang aktif memiliki kemampuan sebagai absorban $\mathrm{NH}_{3}$ (Zhang \& Perschbacher 2003, Supriyono et al. 2007, Supriyono et al. 2011, Nirmala et al. 2012) dengan zeolit yang lebih berpengaruh untuk menurunkan kadar total ammonia-nitrogen (TAN) (Zhang \& Perschbacher 2003).

Tabel 1 Sintasan ikan rono Oryzias sarasinorum selama pengangkutan sistem tertutup berdasarkan perlakuan.

\begin{tabular}{ccccc}
\hline \multirow{2}{*}{ Ulangan } & \multicolumn{5}{c}{ Sintasan (\%) } \\
\cline { 2 - 5 } & $\mathrm{A}$ & $\mathrm{B}$ & $\mathrm{C}$ & $\mathrm{D}$ \\
\hline 1 & 100 & 100 & 100 & 0 \\
2 & 100 & 100 & 75 & 0 \\
3 & 75 & 100 & 25 & 25 \\
\hline Rata-rata & $91,67 \pm 14,43$ & $100,00 \pm 0,00$ & $66,67 \pm 38,19$ & $8,33 \pm 14,43$ \\
\hline
\end{tabular}

Keterangan: $20 \mathrm{~g}$ zeolit $+10 \mathrm{~g}$ arang aktif, tanpa garam (A), $20 \mathrm{~g}$ zeolit $+10 \mathrm{~g}$ arang aktif $+1 \mathrm{~g} \mathrm{~L}^{-1}$ garam (B), $20 \mathrm{~g}$ zeolit $+10 \mathrm{~g}$ arang aktif $+2 \mathrm{~g} \mathrm{~L}^{-1}$ garam $(\mathrm{C})$, tanpa zeolit, arang aktif dan garam (D).

Rendahnya sintasan menjadi masalah dalam pengangkutan ikan. Kematian ikan yang terjadi pada kegiatan pengangkutan disebabkan oleh kandungan $\mathrm{NH}_{3}$ dan $\mathrm{CO}_{2}$ yang melebihi batas toleransi ikan (Supriyono et al. 2007 dan Nirmala et al. 2012). Jika kadar $\mathrm{NH}_{3}$ dalam air meningkat, maka $\mathrm{NH}_{3}$ dari sekresi ikan akan menurun sehingga kandungannya dalam darah dan jaringan meningkat hal ini akan menyebabkan kerusakan insang serta kemampuan darah dalam transpor oksigen (Nirmala et al. 2012). Hasil pengamatan Supriyono et al. (2007) menunjukkan pemberian $20 \mathrm{~g}$ zeolit tanpa arang aktif pada sistem pengepakan tertutup ikan $C$. aenus mampu menekan kenaikan kadar TAN dan $\mathrm{NH}_{3}$. Kemudian pada pengakutan benih ikan patin, penggunaan dosis zeolit $20 \mathrm{~g}$, arang aktif $10 \mathrm{~g}$ dan minyak cengkeh 9 ppm menghasilkan kadar $\mathrm{NH}_{3}$, $\mathrm{CO}_{2}$, dan tingkat stres terendah serta sintasan tertinggi pada pengangkutan tertutup selama 72 jam (Supriyono et al. 2011).

Penambahan garam ke dalam air media pengangkutan bermanfaat untuk menurunkan gradien tekanan osmotik sehingga tingkat stres ikan menjadi lebih rendah. Selain itu juga berfungsi untuk menyediakan ion $\mathrm{Na}^{+}$dan $\mathrm{Cl}^{-}$serta akan meningkatkan ionic strength yang selanjutnya dapat menurunkan toksisitas $\mathrm{NH}_{3}$ (Nirmala et al. 2012). Pada penelitian ini diketahui bahwa penambahan garam $1 \mathrm{~g} \mathrm{~L}^{-1}$ air pada air media pengangkutan yang berisi zeolit dan arang aktif tampaknya memperbaiki sintasan ikan rono selama pengangkutan. Namun penambahan garam $2 \mathrm{~g} \mathrm{~L}^{-1}$ air menyebabkan sintasan lebih rendah (Tabel 1).

Respons setiap ikan berbeda terhadap penambahan garam dalam air media pengangkutan, karena tingkat toleransi yang berbeda-beda.
Penelitian terkait penambahan garam pada air media pengangkutan yang mengandung $20 \mathrm{~g}$ zeolit dan $10 \mathrm{~g}$ arang aktif telah dilakukan pada beberapa jenis ikan dan udang. Nirmala et al. (2012) melaporkan pengangkutan benih ikan gurami melalui penambahan garam $5 \mathrm{~g} \mathrm{~L}^{-1}$ menghasilkan sintasan tertinggi pada pengangkutan dengan kepadatan 50 ekor $\mathrm{L}^{-1}$ selama 72 jam. Penambahan garam $4 \mathrm{~g} \mathrm{~L}^{-1}$ menghasilkan sintasan 3 kali lebih tinggi serta kualitas air lebih baik dibandingkan penambahan yang lebih tinggi $20 \mathrm{~g} \mathrm{~L}^{-1}$ pada pengangkutan benih ikan nila BEST dengan kepadatan 700 ekor $\mathrm{L}^{-1}$ selama 24 jam (Choironawati 2012).

\section{Sintasan pemeliharaan pascapengangkutan}

Pemeliharaan pascapengangkutan untuk menganalisis dampak dari proses pengangkutan ikan, karena efek stres yang selanjutnya berdampak terhadap sintasan berlangsung sekitar dua minggu (Nirmala et al. 2012). Kematian ikan selama periode ini lebih disebabkan oleh pengaruh dari proses pengangkutan. Hasil pengamatan terhadap sintasan ikan rono selama pemeliharaan pascapengangkutan menunjukan kematian ikan terjadi pada hari ke 14, sehingga diperoleh rata-rata sintasan sebesar $88,89 \pm 19 \%$ hari ke 16 pada perlakuan penggunaan zeolit, arang aktif tanpa penambahan garam (A). Pada penggunaan zeolit, arang aktif dan penambahan garam $1 \mathrm{~g} \mathrm{~L}^{-1}$ (B) kematian mulai terjadi setelah hari ke 13 dan terus menurun sehingga diperoleh rata-rata sintasan sebesar $33,33 \pm 58 \%$ pada hari ke 16 . Selanjutnya pada penggunaan zeolit, arang aktif dan penambahan garam $2 \mathrm{~g} \mathrm{~L}^{-1}$ (C) kematian telah terjadi pada hari ke 2 sehingga diperoleh rata-rata sintasan pada hari ke 16 sebesar 55,56 $\pm 51 \%$ (Gambar 3). 


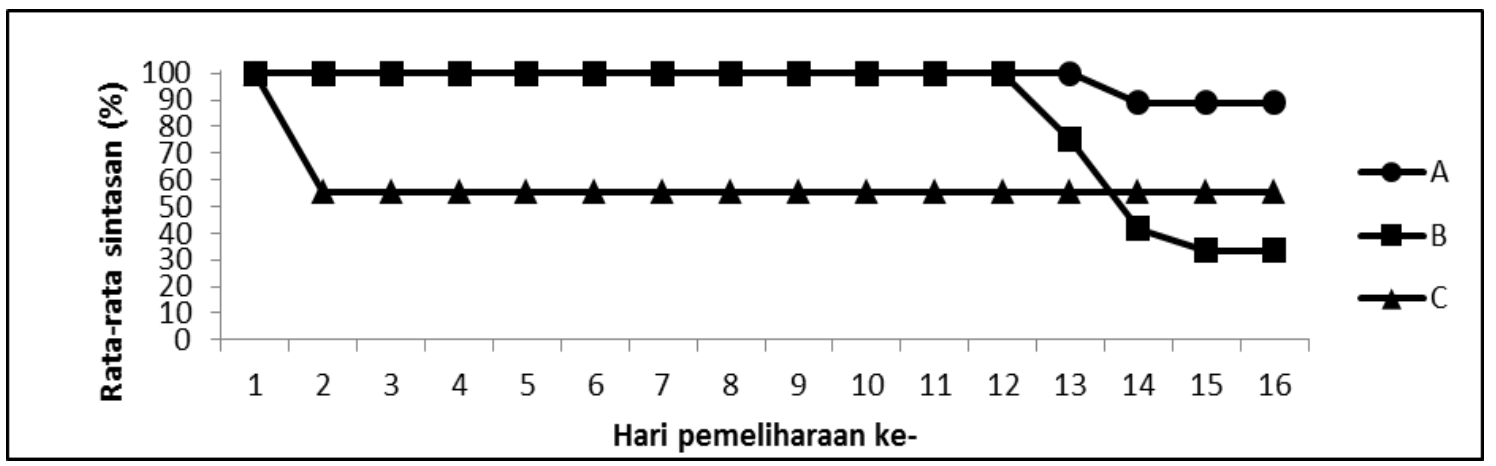

Gambar 3. Sintasan ikan rono Oryzias sarasinorum selama 16 hari pemeliharaan pascapengangkutan. $20 \mathrm{~g}$ zeolit $+10 \mathrm{~g}$ arang aktif, tanpa garam (A), $20 \mathrm{~g}$ zeolit $+10 \mathrm{~g}$ arang aktif $+1 \mathrm{~g} \mathrm{~L}^{-1}$ garam (B), $20 \mathrm{~g}$ zeolit $+10 \mathrm{~g}$ arang aktif $+2 \mathrm{~g} \mathrm{~L}^{-1}$ garam $(\mathrm{C})$.

Respons tiap spesies ikan terhadap penambahan garam saat pengangkutan juga memberikan pengaruh yang berbeda terhadap sintasan saat pemeliharaan pascapengangkutan. Sintasan ikan rono yang lebih rendah pada perlakuan pemberian garam dibandingkan tanpa pemberian garam diduga belum dapat menjaga kondisi fisiologis ikan selama pengangkutan. Perlakuan penggunaan $20 \mathrm{~g}$ zeolit, 10 $\mathrm{g}$ arang aktif tanpa penambahan garam (A) menghasilkan sintasan yang lebih tinggi $62,50 \%$ dibandingkan penambahan $1 \mathrm{~g} \mathrm{~L}^{-1}$ (B) dan $37,50 \%$ dibandingkan penambahan $2 \mathrm{~g} \mathrm{~L}^{-1}$ (C) (Gambar 3). Nirmala et al. (2012) melaporkan bahwa penambahan garam, zeolit dan arang aktif dengan dosis yang tepat dapat membuat ikan lebih nyaman, proses fisiologis ikan tetap berlangsung dengan baik yang berkaitan dengan konsumsi $\mathrm{O}_{2}$ dan ekskresi $\mathrm{NH}_{3}$ serta $\mathrm{CO}_{2}$.

Ikan yang mati pascapengangkutan tertutup, diistilahkan dengan hauling loss. Nirmala et al. (2012) melaporkan rata-rata kematian benih ikan gurami terjadi pada hari kedua sampai ketiga. Kemudian penambahan garam $5 \mathrm{~g} \mathrm{~L}^{-1}$ dalam air media pengangkutan dapat meningkatkan sintasan benih ikan gurami sebesar $17 \%$ dibandingkan tanpa penambahan garam selama 17 hari pemeliharaan pascatransportasi. Ramírez-Duarte et al. (2011) melaporkan penambahan sodium klorida sebanyak 1 $\mathrm{g} \mathrm{L}^{-1}$ dapat menekan stres dan menekan kematian ikan Ancistrus triradiatus selama pemeliharaan 7 hari setelah pengangkutan. Pemberian garam yang terlampau tinggi juga tidak baik untuk sintasan ikan. Choironawati (2012) melaporkan pemberian garam 4 g $\mathrm{L}^{-1}$ menghasilkan sintasan lebih tinggi 7,7\% dibandingkan dosis $20 \mathrm{~g} \mathrm{~L}^{-1}$ saat transportasi ikan nila BEST dengan kepadatan 700 ekor $\mathrm{L}^{-1}$ selama 24 jam setelah 20 hari pemeliharaan.

\section{SIMPULAN}

Habitat ikan rono Oryzias sarasinorum di pesisir Lovu, danau Lindu yaitu memiliki dasar landai, substrat pasir kasar, warna air cokelat-teh, terdapat serasah, tanaman air dala Phragmites karka.
Larva dan juwana ikan rono berenang bergerombol di sekitar tanaman dala yang terendam air. Ikan rono muda dan dewasa terlihat makan di atas substrat dasar perairan. Spesies ikan lain yang ditemukan di habitat ini yaitu nila Oreochromis sp., sepat Trichopodus sp. serta Gambusia affinis. Penggunaan zeolit $20 \mathrm{~g}$, arang aktif $10 \mathrm{~g}$ di air media pengangkutan sistem tertutup ikan rono Oryzias sarasinorum dapat meningkatkan sintasan dibandingkan tanpa menggunakan zeolit dan arang aktif. Kemudian penggunaan zeolit, arang aktif dan tanpa garam memberikan sintasan yang lebih tinggi $62,50 \%$ dibandingkan penambahan garam $1 \mathrm{~g} \mathrm{~L}^{-1}$ dan $37,50 \%$ dengan penambahan garam $2 \mathrm{~g} \mathrm{~L}^{-1}$ selama pemeliharaan pascapengangkutan pada penelitian ini. Selain itu, penambahan substrat pasir untuk pemeliharaan ikan rono dalam wadah terkontrol dapat dipertimbangkan untuk meniru habitat alaminya.

\section{UCAPAN TERIMA KASIH}

Kami mengucapkan terima kasih kepada bapak Rusaini, PhD dan bapak Dr. Syahrir yang mengizinkan penggunaan fasilitas Laboratorium Kualitas Air dan Biologi Akuatik serta mengizinkan Himpunan Mahasiswa Perikanan (HIMARIN) FAPETKAN, UNTAD, untuk ikut serta dalam Ekspedisi Riset Akuatika (ERA) di danau Lindu. Bapak Dr. Fadly Y. Tantu yang memberikan masukan kepada tim ERA. Bapak kepala dinas Ketahanan Pangan dan Perikanan, Kabupaten Sigi yang mengizinkan penggunaan fasilitas daerah di danau Lindu. Bapak Suwignyo dan istri, serta keluarga saudara Alyandro yang membatu akomodasi selama di danau Lindu. Kusmadi SPi, M.I. Mubaraq SPi, Sutoyo SPi, A. Radinal SPi, A. Mutmainnah dan seluruh rekan-rekan tim ERA serta HIMARIN yang membantu selama ekspedisi.

\section{DAFTAR PUSTAKA}

Annawaty, \& Wowor, D. (2015). The atyid shrimp from Lake Lindu, Central Sulawesi, Indonesia 
with description of two new species (Crustacea: Decapoda: Caridea). Zootaxa. 3957(5): 501-519.

Choironawati, A. (2012). Pemanfaatan zeolit dan karbon aktif dalam transportasi tertutup benih ikan nila BEST Oreochromis sp. dengan kadar garam berbeda. [Skripsi]. Bogor (ID): Institut Pertanian Bogor.

Gani, A., Nilawati, J., \& Rizal, A. (2015). Studi habitat dan kebiasaan makanan (food habit) ikan rono Lindu (Oryzias sarasinorum Popta, 1905). Jurnal Sains dan Teknologi Tadulako. 4(3): 9-18.

Gundo, M.T. (2016). Konservasi ikan endemik rono, Xenopoecilus oophorus, Kottelat 1990 di danau Poso, Sulawesi Tengah. [Disertasi]. Bogor (ID): Institut Pertanian Bogor.

Haryono, Rahardjo, M.F., Affandi, R., \& Mulyadi. (2017). Karakteristik morfologi dan habitat ikan brek (Barbonymus balleroides Val. 1842) di sungai Serayu Jawa Tengah. Jurnal Biologi Indonesia. 13(2): 223-232.

Herder, F., \& Chapuis, S. (2010). Oryzias hadiatyae, a new species of ricefish (Atherinomorpha: Beloniformes: Adrianichthyidae) endemic to lake Masapi, Central Sulawesi, Indonesia. The Raffles Buletin of Zoology. 58(2): 93-104.

Lukman. (2007). Danau Lindu keteduhan yang merindu. LIPI Press, Jakarta. 68 p.

Mokodongan, D.F., Tanaka, R., \& Yamahira, K. (2014). A new ricefish of the genus Oryzias (Beloniformes, Adrianichthyidae) from lake Tiu, Central Sulawesi, Indonesia. Copeia. 2014(3): 561-567.

Nirmala, K., Hadiroseyani, Y., \& Widiasto, R.P. (2012). Penambahan garam dalam air media yang berisi zeolit dan arang aktif pada transportasi tertutup benih ikan gurami Ospronemus goramy Lac. Jurnal Akuakultur Indonesia. 11(2): 190-201.

Parenti, L.R, \& Soeroto, B. (2003). Adrianichthys roseni and Oryzias nebulosus, two new ricefishes (Atherinomorpha: Beloniformes: Adrianichthyidae) from lake Poso, Sulawesi, Indonesia. Ichthyological Research. 51(1): 1019.

Parenti, L.R. (2008). A phylogenetic analysis and taxonomic revision of ricefishes, Oryzias and relatives (Beloniformes, Adrianichthyidae). Zoological Journal of the Linnean Society. 154(3): 494-610.

Ramírez-Duarte, W.F., Pineda-Quiroga, C., Martinez, N., \& Eslava-Mocha, P.R. (2011). Use of sodium chloride and zeolite during shipment of Ancistrus triradiatus under high temperature. Neotropical Ichthyology. 9(4): 909-914.

Rasmina. (2014). Studi ekobiologi ikan Xenopoecilus sarasinorum endemik danau Lindu sebagai dasar untuk budidaya. [Skripsi]. Palu (ID): Universitas Tadulako.
Supriyono, E., Supendi, A., \& Nirmala, K. (2007). Pemanfaatan zeolit dan karbon aktif pada sistem pengepakan ikan corydoras, Corydoras aenus. Jurnal Akuakultur Indonesia. 6(2): 135-145.

Supriyono, E., Syahputra, R., Ghozali, M.F.R., Wahjuningrum, D., Nirmala, K., \& Kristanto, A.H. (2011). Efektivitas pemberian zeolit, arang aktif, dan minyak cengkeh terhadap hormon kortisol dan gambaran darah benih ikan patin Pangasionodon hypophthalmus pada pengangkutan dengan kepadatan tinggi. Jurnal Iktiologi Indonesia. 11(1): 67-75.

Wilkerson, A. (2013). Domestikasi ikan endemik danau Lindu Xenopoecilus sarasinorum dengan pemberian jenis pakan berbeda. [Skripsi]. Palu (ID): Universitas Tadulako.

Yustiati, A., Pribadi. S.S., Rizal, A., \& Lili W. (2017). Pengaruh kepadatan pada pengangkutan dengan suhu rendah terhadap kadar glukosa darah dan kelulusan hidup ikan nila (Oreochromis niloticus). Jurnal Akuatika Indonesia. 2(2): 137-145.

Zhang, Z., \& Perschbacher, P. (2003). Comparison of the zeolite sodium chabazite and activated charcoal for ammonia control in sealed containers. Asian Fisheries Science. 16(2): 141-145. 